\title{
The Arabist from Shemakha Who Dreamed of the Sea: Theodor Adamovich Shumovsky (1913-2012)
}

\author{
V. O. Bobrovnikov ${ }^{1,2,3}$
}

${ }^{1}$ Institute of Oriental Studies, Russian Academy of Sciences, 12 Rozhdestvenka str., Moscow
107031 , Russian Federation
${ }^{2}$ Saint Petersburg State University, 7-9 Universitetskaya Embankment, St. Petersburg 199034,
Russian Federation
${ }^{3}$ National Research University Higher School of Economics, 16 Soyuz Pechatnikov str., Saint
Petersburg 190121, Russian Federation

DOI: $10.18255 / 1996-5648-2021-2-136-151$

Research article Full text in Russian

The twentieth century witnessed heyday of the Russian-Soviet Arabic and Islamic studies, whose academic school created by Victor von Rosen and his disciple Ignaty Krachkovsky had flourished already in the late Russian empire and survived the Soviet period. Its representa-tives included many outstanding yet controversial figures, whose scientific biography still needs to be rethought in the context of late post-colonial Orientalism under the Stalinist rule and the Cold War period. One of these scholars was Theodor Adamovich Shumovsky, political prisoner, poet and memoirist. He belonged to the last generation of students of I. Yu. Krachkovsky, specialized in early modern Arabic maritime geography, later translated the Qur'an into Russian in verses. The present work attempts to give a comprehensive discursive analysis of the work of this maritime Arabist, with whom the author knew well in the last decade of his life.

Keywords: Post-colonialism; Arabic studies; Orientalism; Shumovsky; text studies; Arabic maritime geography; translations of the Qur'an

\section{INFORMATION ABOUT AUTHORS}

\begin{tabular}{l|l} 
Bobrovnikov, Vladimir O. & E-mail: vladimir_bobrovn@mail.ru \\
Cand. Sc. (History), Professor \\
Central Eurasian Research Center in Institute \\
of Oriental Studies, Russian Academy of Sciences, \\
Moscow; \\
Research Fellow in Research Laboratory for \\
Analysis and Modeling of Social Processes, Saint \\
Petersburg State University; \\
Professor in Department of History, National \\
Research University Higher School of Economics \\
in St. Petersburg
\end{tabular}

(C) Bobrovnikov V. O., 2021

This is an open access article under the CC BY license (https://creativecommons.org/licenses/by/4.0/) 


\section{Мечтавший о море арабист \\ из Шемахи: Теодор Адамович \\ Шумовский (1913-2012)}

В. О. Бобровников ${ }^{1,2,3}$

${ }^{1}$ Институт востоковедения РАН, ул. Рождественка, 12, 107031, Москва, Российская Федерация
${ }^{2}$ Санкт-Петурбургский государственный университет, Университетская набережная, 7-9,
Санкт-Петербург, 199034, Российская Федерация
${ }^{3}$ Национальный исследовательский университет «Высшая школа экономики», Союза
Печатников ул., 16, Санкт-Петербург, 190121, Российская Федерация

DOI: $10.18255 / 1996-5648-2021-2-136-151$

Научная статья

УДК 929:930.2+93/94

Полный текст на русском языке

ХХ в. был временем расцвета российско-советской арабистики и исламоведения. Академическая школа В. Р. Розена (1849-1908) - И. Ю. Крачковского (1883-1951, сложившаяся в С.-Петербурге при поздней Российской империи, пережила советскую эпоху. В ней было немало блестящих и неоднозначных фигур. Их научные биографии еще нуждаются в переосмыслении в контексте позднего постколониального ориентализма эпохи сталинизма и «холодной войны». Одной из таких личностей был Теодор Адамович Шумовский - один из последних учеников И. Ю. Крачковского, редкий специалист по арабской морской географии раннего нового времени, создатель единственного поэтического перевода Корана на русский язык, политический заключенный, поэт и мемуарист. Настоящая работа представляет комплексный дискурсивный анализ творчества ученого, которого автор статьи близко знал в последнее десятилетие его жизни.

Ключевые слова: постколониализм; арабистика; ориентализм; Шумовский; текстология; арабская морская география; переводы Корана

\section{ИНФОРМАЦИЯ ОБ АВТОРАХ}

Бобровников, Владимир Олегович

(C) Бобровников В. О., 2021
E-mail: vladimir_bobrovn@mail.ru

Кандидат исторических наук, профессор, Центр изучения Центральной Азии, Кавказа и Урало-Поволжья Института востоковедения РАН, Москва; научный сотрудник Научной лаборатории по анализу и моделированию социальных процессов Санкт-Петербургского государственного университета; профессор Департамента истории Национального исследовательского университета «Высшая школа экономики» в Санкт-Петербурге

Статья открытого доступа под лицензией СС BY (https://creativecommons.org/licenses/by/4.0/) 
Бобровников В. О.

Бывшая столица ширваншахов г. Шемаха лежит далеко от Каспия в предгорьях Большого Кавказа. В отличие от не менее древней Севильи на Гвадалквивире, ставшей после открытия Америки главным торговым морским портом Испанской империи с Вест-Индиями, а с конца XVIII в. еще и богатейшим архивным центром по испанским колониям в Америке, и других культурных центров Евразии древний мусульманский политический и культурный центр в Азербайджане не связан с мореплаванием. Даже большой реки в окрестностях города нет. Но у знатоков русской культуры название города может вызвать в памяти восточную музыку бредившего морем Н. А. Римского-Корсакова, написавшего в 1888 г. сюиту «Шехеразада», а в 1908 г. - оперу по сказке А. С. Пушкина о Шамаханской царице («Золотой петушок»), и подчеркнуто ориенталистские декорации к ним художников Серебряного века И. Я. Билибина и К. А. Коровина.

Известных исторических памятников и достопримечательностей в Шемахе немало, но место города и в целом российско-советского Кавказа в истории отечественной арабистики изучено недостаточно. В первой трети $\mathrm{XX}$ века, когда Шемаха принадлежала сначала Российской империи, а затем Советскому Союзу, здесь прошли детство и юность оригинального советского арабиста, одного из редких специалистов по арабской морской географии Теодора Адамовича Шумовского, востоковеда, поэта, мыслителя, для которого наследие русского ориентализма на Кавказе много значило. При некоторой нестандартности его научная биография представляет хороший материал для изучения тематики, методологии и стиля исследований мусульманского Востока в советской академической ориенталистике XX в.

Т. А. Шумовский прожил долгую жизнь длиною в столетие и скончался в Санкт-Петербурге 28 февраля 2012 г., справив незадолго до этого свое 99-летие. Он принадлежал к классической ленинградской школе русской арабистики. Его юность пришлась на пору ее расцвета в первые десятилетия после революции 1917 г.

Будущий востоковед родился в большой интеллигентной польской семье на западных окраинах Российской империи, в Житомире, 2 февраля 1913 г., а вырос в Азербайджане, куда, спасаясь от Первой мировой войны, в 1915 г. переехали его родители. В Шемахе, где семья отца жила с 1922 г., у него, по его собственным словам, с 8 лет родился интерес к изучению арабо-мусульманского Востока [1, с. 173; 2, с. 52]. Окончив школу, он уезжает в Москву с горячим желанием поступить в "вуз по арабскому языку» $[1$, c. 14]. После долгих мытарств, побывав студентом бакинского Техникума нефтяного машиностроения, московского Горного института и забойщиком на шахте «Ирмино 4/2 бис» в Донбассе, в сентябре 1932 г. он был зачислен на арабское отделение Ленинградского историко-лингвистического института - ЛИЛИ, как шутливо его тогда называли (рис. 1) [1, с. 16-19; 3, с. 430¹].

${ }^{1}$ Расширенное издание см.: http://memory.pvost.org/pages/shumovskij.html (дата обращения: 30.01.2021). 


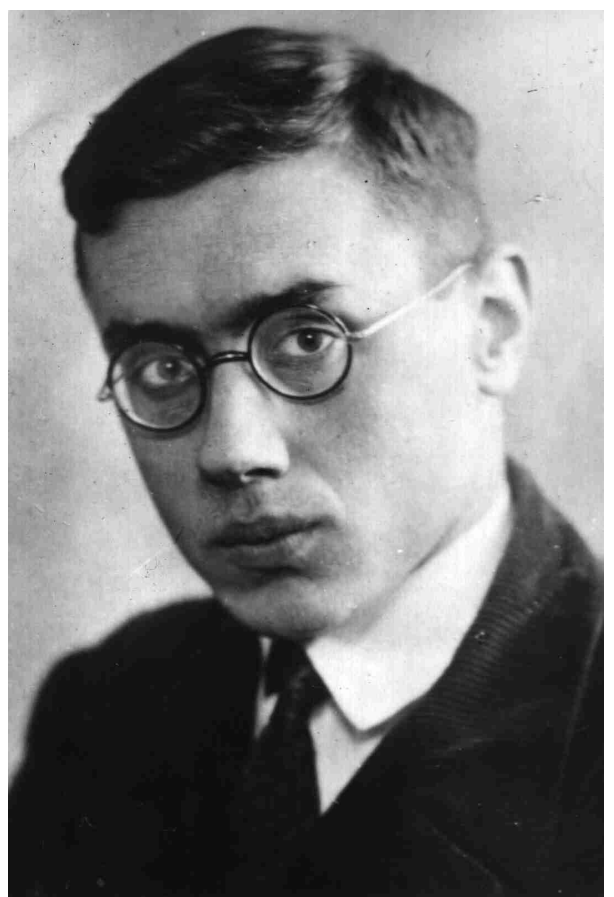

Рис. 1. Т.А. Шумовский, студент Ленинградского университета. 1938 г. (Личный архив В.Т. Шумовского).

С этого времени судьба Шумовского связана с Ленинградом, но до старости он не забывал Шемахи, овеянной для него романтическими воспоминаниями детства. Город вызывал в памяти ученого целый ряд коротких бытовых зарисовок, передающих читателям воспоминаний Шумовского аромат его пряной восточной экзотики, давая возможность почувствовать впечатления автора, когда тот был еще студентом и, как по мановению волшебной палочки, переносился из бурной советской эпохи 1930-х гг. в глухое средневековье. «Узкие кривые улицы, мощенные булыжником, уходят вниз. Руины <..> Руины < ..> Руины < ..> Когда-то тут были дома и сады, фронтаны и бани, лавки купцов и мечети с высоко взметнувшимися минаретами... Шемаха окружена поясом кладбищ - четыре мусульманских, армянское, русское <...> Под тяжкой десницею времени незримо склоняются стоящие и врастают в землю лежащие плиты. Время и тишина - два царя царствуют здесь <..>. Мне вспомнилось, как в 1922 году, еще мальчиком, я расширенными от ужаса и любопытства глазами наблюдал из верхнего города религиозную процессию шиитов, шедшую где-то здесь, по этим каменистым улицам. Громадная толпа мерно колыхалась, полуголые люди били себя одни кинжалами по голове, другие цепями по плечам, стоны боли тонули в криках: “Шах Хусейн! Вах Хусейн! Шах Хусейн! Вах Хусейн!” Я еще не знал тогда, что Хусейн - внук основателя ислама Мухаммеда, сражен- 
ный в битве при Кербела в 680 году; его гибель шииты, одно из двух крупнейших направлений мусульманства, оплакивают уже не менее тринадцати столетий... Все больше крови обагряло пыльные камни, все большее исступление овладевало процессией. И потом < .. > не сюда ли она повернула, не здесь ли запылали костры, на которых кипели котлы с мясом жертвенных баранов» [1, с. 174-176; 2, с. 53-55]. Очень живая сценка! Как будто рассматриваешь раскрашенные ориенталистские почтовые карточки по Кавказу начала XX в. или В. В. Верещагина, читаешь путевые заметки художника, посетившего Шушу в 1865 г. и не менее Шумовского пораженного траурными процессиями шиитов на 'Ашуру (рис. 2). Не исключено, что, подобно В. В. Верещагину, автор воспоминаний не мог удержаться от соблазна поразить читателя экзотикой мусульманского Востока России.

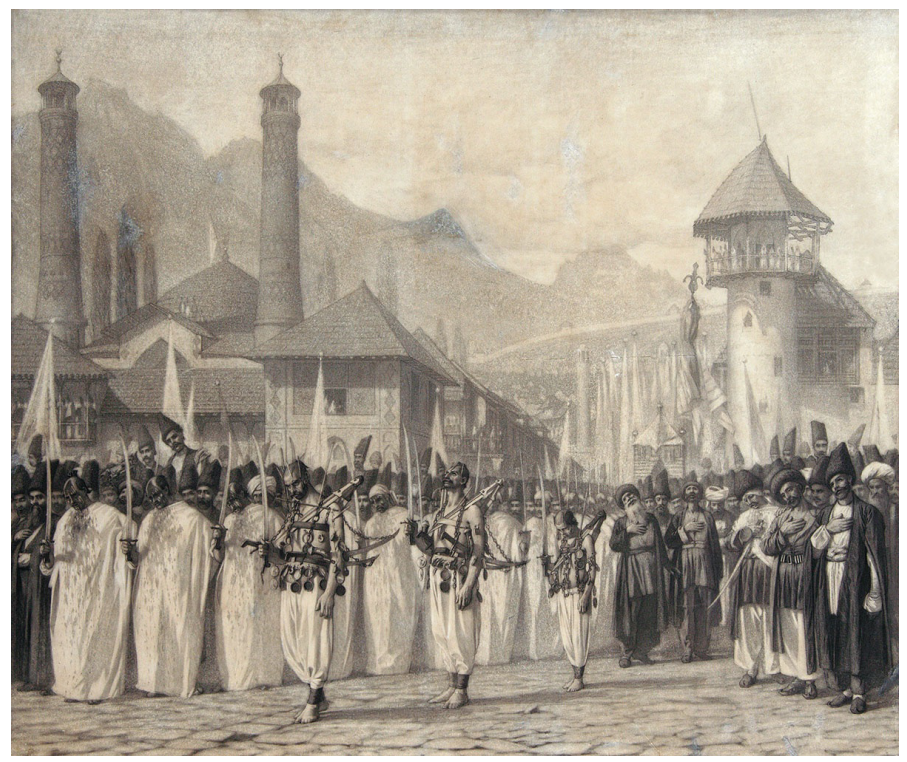

Рис. 2. В. В. Верещагин. Религиозная процессия на празднике Мохаррем в Шуше, 1865 г. (Государственная Третьяковская галерея).

Тюркоязычная Шемаха осталась для Шумовского в прошлом. С университетской скамьи он погрузился в историю арабского Ближнего Востока. Будущему ученому выпало счастье учиться у классиков отечественной арабистики и исламоведения. Его первым учителем в арабском языке был крупный лингвист Н. В. Юшманов. На старших курсах Шумовский занимался у К. В. Оде-Васильевой, В. И. Беляева, А. Ю. Якубовского, В. А. Крачковской, слушал лекции египтолога В. В. Струве, кавказоведа-арабиста А. Н. Генко. (С последним судьба еще раз свела его весной и летом 1938 г. в камере ленинградского дома предварительного заключения НКВД на ул. Воинова [4, с. 141-142]). Шумовский стал одним из последних учеников И. Ю. Крачковского, с его подачи занялся исследованием арабского мореплавания рубе- 
жа средневековья и нового времени. Студентом пятого курса он начал переводить лоции Индийского океана моряка конца XV в. Ахмада ибн Маджида. Годы ученичества и приход в востоковедение ученый увлекательно описал почти полвека спустя в книге воспоминаний, вышедшей на закате советской эпохи под названием, выдающим давнее увлечение автора («У моря арабистики») [1, с. 9-134; 5].

Арабисты классической школы, к которой принадлежали университетские учителя Шумовского, изучали в основном средневековые и древние тексты на восточных языках; работа с ними целиком поглощала их внимание. Художественные особенности сочинений, их человеческое измерение, как правило, классиков не интересовали. По своей специальности Шумовский был источниковедом-текстологом. Он перевел и прокомментировал сохранившиеся в Институте востоковедения в Ленинграде (ныне Институт восточных рукописей РАН) и Национальной библиотеке Франции в Париже (Bibliothèque nationale de France) арабские рукописи трудов Ахмада ибн Маджида, который, по преданию, провел в 1498 г. корабли португальской эскадры Васко де Гамы от Восточного побережья Африки в Индию, затем лоции его младшего современника Сулаймана ал-Махри (1480-1550) (рис. 3).

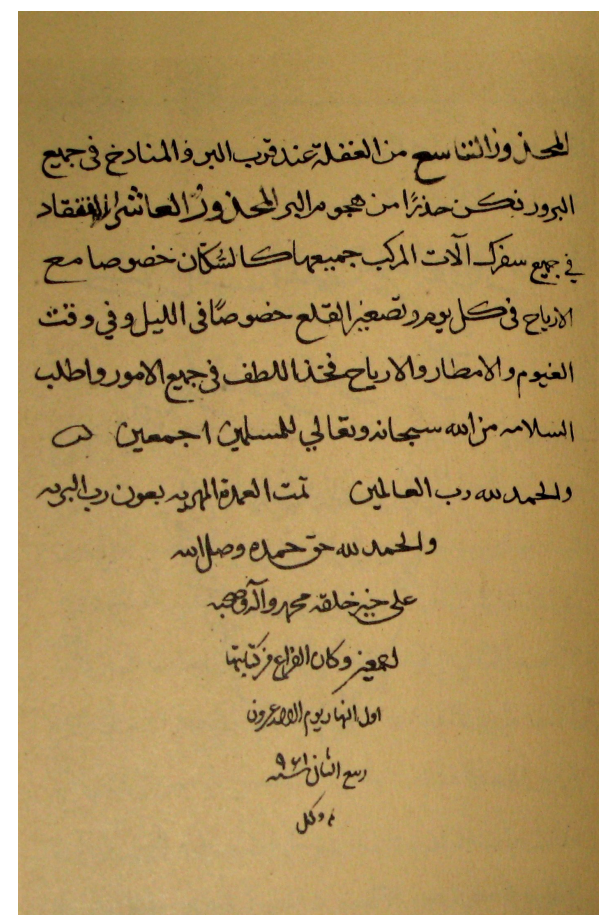

Рис. 3. Ал-Махри, Сулайман. Ал-'Умда ал-махрийа фри дабт ал-'улум ал-бахрийа (Арабская лоция по Индийскому океану). Колофон. Рук. 961/1554 г.

(Bibliothèque nationale de France. Arabe 2559. P. 59r). 
Бобровников В. О.

Шумовский следовал принципам перевода, принятым в отечественной арабистике; ее классическим образцом остается «Тысяча и одна ночь» в переводе другого известного ученика И. Ю. Крачковского - М. А. Салье [6]. Переводчик пытался максимально приблизить перевод к оригиналу, создавая его буквальный подстрочник, перенося в русский не свойственные ему арабские конструкции, избегая современных понятий, а нередко намеренно архаизируя язык перевода. В этом духе написаны основные ученые труды Шумовского конца 1940 - середины 1980-х гг.

В 1948 г. он защитил в Ленинграде кандидатскую диссертацию «Три неизвестные лоции Ахмада ибн Маджида, арабского лоцмана Васко да Гамы, в уникальной рукописи Института востоковедения АН СССР». Она была опубликована под тем же названием в 1957 г. В 1985 и 1986 гг. за ней последовали два пухлых тома «Книги польз об основах и правилах морской науки» Ахмада ибн Маджида, содержащих критический арабский текст, перевод, комментарии и историко-географическое исследование его энциклопедического трактата «Китаб ал-фрава'ид фри-усул 'илм ал-бахр ва-л-кава“ид». Русский перевод памятника пять раз перерабатывался Шумовским! Первый его вариант сам переводчик назовет позднее «ремесленным». Четвертую версию он сознательно стилизовал под русский язык XVIII-XIX столетий, пытаясь передать исторический колорит рукописи XV в., но в конечном варианте решил обойтись без чрезмерной архаизации. В 1968 г. на основе этой работы он защитил в Москве докторскую диссертацию по истории средневековой арабской морской географии.

В 1975 г. Шумовский подготовил к печати перевод «Махрийской опоры для прочного приобретения морских знаний» Сулаймана аль-Махри. По ряду причин публикация книги задержалась до 2011 г. [7].

Название докторской диссертации Шумовского было таким же, что и у научно-популярной книги, выпущенной за четыре года до того в Москве, - «Арабы и море» [8]. Заголовок - простой, сильный и вызывающий: арабы ассоциируются у российского и вообще европейского читателя не с морем, а с сушей, прежде всего с безводными пустынями Ближнего Востока и Северной Африки. О значении моря в истории арабской культуры, общества и государственности читатель узнает со страниц книги. Один из ее главных постулатов состоит в признании давних связей Европы с мусульманским Востоком.

По смелому предположению Шумовского, эпоха Великих географических открытий опиралась на достижения средневековых арабских географов и мореплавателей. Задолго до европейского продвижения на Восток они освоили Средиземноморье и Индийский океан с частью Тихого. Пример Ибн Маджида показывает, что арабские лоцманы участвовали в морских экспедициях европейских первооткрывателей. К близким, хотя и более осторожным, выводам пришли и западные медиевисты, предпочитающие говорить о тесных контактах Европы с «миром ислама» со времен крестовых походов. Создан- 
ный ориенталистами колониальной эпохи образ арабов как боявшихся моря «диких сынов пустыни» во многом отвергнут сегодня [9, с. 71-72].

Не следует думать, что научная карьера Теодора Адамовича складывалась легко и успешно. Советская политика и чиновники не раз ломали его судьбу. В юности он пережил два ареста, почти пятнадцать лет провел в сталинских концлагерях смерти и в ссылке в Сибири. В ночь с 10 на 11 февраля 1938 г., вместе со студентами Ленинградского университета Н. П. Ериховичем и Л. Н. Гумилевым, в будущем крупнейшим советским евразийцем, он был арестован по сорабрикованному НКВД делу об антисоветской «партии прогрессистов». Все трое были отправлены в лагеря, где, несмотря на тяжелые условия существования, Шумовский пытался изучать языки - от фринского до китайского. Выпущенный без права жить в Ленинграде, он сдал госэкзамены и закончил в 1946 г. университет, работал в новгородском Институте усовершенствования учителей в г. Боровичи, написал и успел защитить под руководством И. Ю. Крачковского кандидатскую диссертацию. В январе 1949 г. последовал второй арест и приговор к 10 годам заключения в Озёрлаге в Краснодарском крае. Смерть Сталина позволила досрочно выйти на свободу в 1956 г. Первые месяцы после лагеря он жил в Восточной Сибири, там же сделана редкая фотокарточка зимы 1956 г. Шумовский снялся в ватнике на фоне плохонькой копии картины дореволюционного мариниста с парусником на якоре у гор (рис. 4).

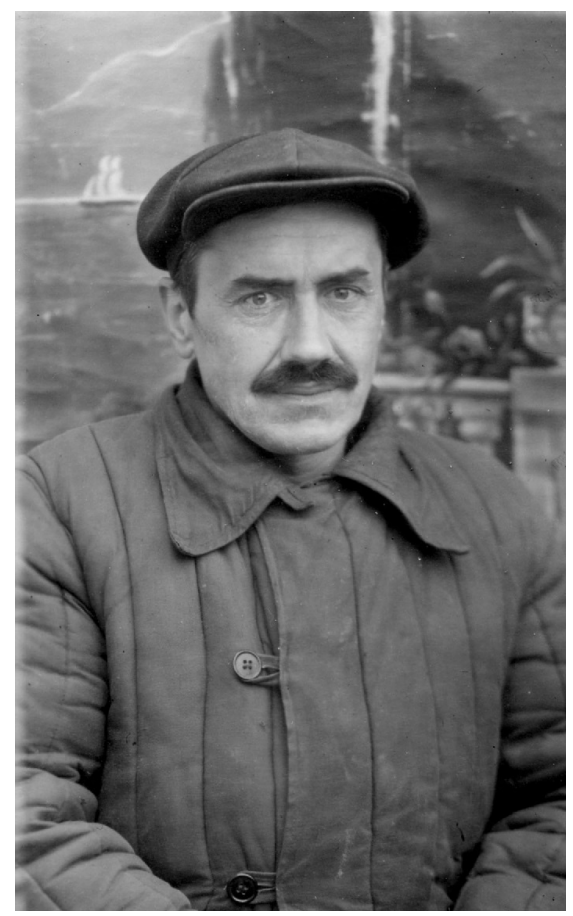

Рис. 4. Т.А. Шумовский после освобождения из Озерлага. Тайшет, 1956 г. (Личный архив В.Т. Шумовского). 
4 апреля он уехал в Москву, но полной реабилитации добился только в 1963 г. Благодаря поддержке академика И. А. Орбели и Н. В. Пигулевской (И. Ю. Крачковский к этому времени скончался), Шумовский поступил на работу в Ленинградский филиал Института Востоковедения АН СССР [2, с. $67-214 ; 3$, с. 430], в знаменитом Арабском кабинете которого работал с 1956 г. до выхода на пенсию в 1979 г.

Когда из печати вышли первые работы Шумовского, политические репрессии в СССР утратили массовый характер, «культ личности» был официально осужден в 1956 г. Перед ученым, как и перед миллионами его современников, сумевших сохранить жизнь в сталинской мясорубке, хамовато «извинились», но оба его дела были закрыты. Однако привлекать внимание читателя к эпохе Сталина при Брежневе стало не принято, и Шумовский в воспоминаниях, опубликованных в 1960-гг., лишь мимоходом неопределенно отметил, что в прошлом был дважды репрессирован, а позднее реабилитирован в 1957 г. Случаи давления власти на науку в эпоху «застоя» стремились не предавать гласности.

Официальная биография ученого в знаменитом биобиблиографическом справочнике советских востоковедов С. Д. Милибанд ни о каких посадках, конечно, не упоминает [10, с. 619]. В статье о нем указан лишь год окончания университета (1946) без даты поступления, чтобы у читателя не возникло ненужных вопросов, почему учеба в вузе затянулась почти на 15 лет.

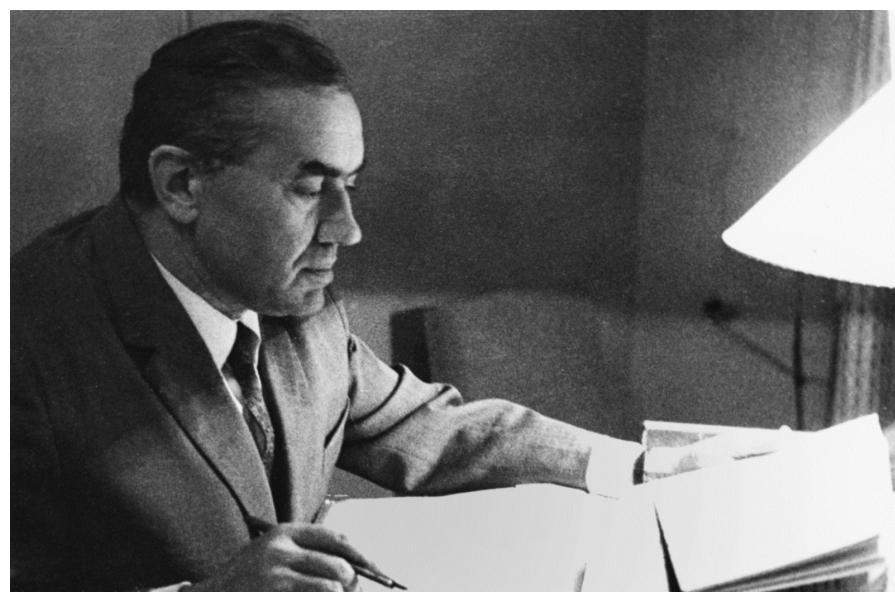

Рис. 5. Т. А. Шумовский, младший научный сотрудник Ленинградского отделения Института востоковедения (ныне: Институт восточных рукописей РАН). Ленинград, 1956 г. (Личный архив В.Т. Шумовского).

С 1956 г. научная биография Шумовского (рис. 5) складывалась счастливее, опять же не без влияния политики, связанной с распространением советского влияния на постколониальный Восток. Почему в разгар «холодной войны», в 1957 г., молодому, беспартийному, политически неблагона- 
дежному бывшему зеку, маловлиятельному Шумовскому удалось быстро издать свой перевод и труд об Ибн Маджиде на нескольких языках? Только из-за того, что в дело вмешался Суэцкий кризис. 26 июля 1956 г. в ответ на отказ США и Великобритании финансировать строительство Асуанской плотины президент Египта Г. А. Насер решил национализировать Суэцкий канал. Тогда Великобритания и Франция подтолкнули Израиль оккупировать Синай в конце октября. В районе Порт-Саида высадился фрранко-британский десант. 5 ноября СССР направил Великобритании, Франции и Израилю ультиматум. Советское правительство заявило о решимости «применением силы сокрушить агрессоров», если боевые действия против Египта не будут прекращены. При поддержке США советским дипломатам удалось разрешить Суэцкий кризис в пользу правительства Насера. В декабре 1956 г. фрранко-британские, а в марте 1957 г. израильские войска покинули территорию Египта.

Одновременно в СССР и союзных ему арабских государствах развернулась широкая пропагандистская кампания. Перед академической наукой была поставлена цель доказать западноевропейским политикам и ученым существование у арабов древних и независимых от европейцев традиций мореплавания. Для решения этой идеологической задачи как нельзя кстати пришлись арабские лоции, которыми занимался Шумовский. Рукопись его чернового перевода была проведена через Ученый совет Института востоковедения, во главе которого с 1956 г. стоял талантливый организатор науки, переведенный Хрущевым из Душанбе в Москву бывший первый секретарь ЦК КП Таджикистана Бободжан Гафруров, и срочно издана в 1957 г.

Книга содержала характерное для тех лет посвящение «свободолюбивым арабским народам с пожеланием больших счастливых плаваний» [11, с. 2]. Издание вызвало интерес у арабских и западных ученых. За границу автора не выпустили. На Международный конгресс по истории географических открытий в Лиссабон в 1960 г. был отправлен только его доклад, ставший первой зарубежной публикацией ученого. Для выезда он был слишком инакомыслящим, не таким правоверным советским марксистом и отнюдь не политиком, как его старший брат Станислав, крупный номенклатурный работник, военный и разведчик. Однако еще в 1930-е гг. Станислав порвал с братом и семьей покойного отца, сменив даже национальность на украинца и отчество на Антонович [12; 2 , с. 10].

В том же 1960 г. исследование Теодора Шумовского об Ибн Маджиде появилось в Лиссабоне на португальском языке, в 1966 г. в Дамаске и в 1969 г. в Каире - на арабском [13; 14]. Издания были небезупречны. Авторитетные зарубежные востоковеды критиковали их за отсутствие критического текста арабского оригинала, неточности в переводе специальной морской терминологии, спорные комментарии [15, р. 349]. Ответить 
Бобровников В. О.

на замечания зарубежных коллег и подготовить критическое издание памятника Шумовский смог много позднее, к середине 1980-х гг.

Шумовский немало сделал для популяризации истории ориенталистики и источниковедения. Его научно-популярная брошюра «Арабы и море» была приурочена к 500-летнему юбилею появления поэмы Ахмада ибн Маджида об основах науки морей, законченной в 1462 г. В том же году, как уже отмечалось, в том же издательстве «Наука» появились «Воспоминания арабиста», а в 1975 г. - «У моря арабистики». В 1986 г. была издана научно-популярная книга «По следам Синдбада-морехода. Океанская Аравия». По признанию автора, этот персонаж из сказок «Тысяча и одна ночь», наряду с главами рассыпавшегося дореволюционного учебника истории о сарацинах и стране ал-Андалус (мусульманской Испании), занимал его с детства, проведенного в экзотической, полной мусульманских кладбищ и мечетей Шемахе [1, с. 13].

В постсоветскую эпоху «Издательский дом Марджани» в Москве напечатал второе издание «Арабов и моря» (2010); ранее, в 1999 г., Санкт-Петербургский университет издал монографию Шумовского «Последний “лев арабских морей”: Жћизнь арабского мореплавателя и поэта Ахмада ибн Маджида, наставника Васко да Гамы». В ее названии автор обыграл прозвище (Асад ал-бахр), под которым его герой был известен в арабской морской географии.

Книги были адресованы широкому кругу читателей, интересующихся арабо-мусульманским Востоком. Их целью было показать, что в прошлом арабы были связаны с морем гораздо теснее, чем считается: об этом зримо говорят средневековые арабские карты и лоции. По мнению Шумовского, вошедшие в европейские языки многочисленные арабские названия созвездий являются свидетельством существования у древних арабов развитой навигации. На примере Ибн Маджида он доказывал, что арабские лоцманы участвовали в экспедициях европейских первооткрывателей.

Не все выводы научно-популярных работ Шумовского подкреплены конкретными фрактами. Порой они производят впечатление парадоксальных. Но при некотором преувеличении есть в них и зерно истины. К похожим выводам ранее пришли классик отечественного востоковедения В. В. Бартольд, указавший на наличие морских реминисценций в Коране [16, с. 544-548], и западные медиевисты, отвергшие господствующую ранее точку зрения Анри Пиренна о том, что создание Арабского халифата надолго прервало морские контакты Европы с Азией [9, с. 72].

Издания арабских лоций принесли Шумовскому славу, хотя его гипотеза о том, что арабы были настоящими викингами мусульманского Востока и исследователями Окена, не была полностью принята в академической науке [17, с. 415, 423]. Не каждому дано увлечь читателя повествованием о старых, непонятных для неспециалиста рукописях и заботах историка. Автор «Арабов и моря» смог не только профессионально сделать работу 
историка, но живо и увлекательно описать ее на хорошем русском языке. Академическая наука пока слишком мало задумывалась над фрормой изложения и передачи текстов источников.

Большую роль в арабо-мусульманской науке играла поэзия. Различные авторы, со времен возникновения ислама и раньше, нередко выражали свои мысли в стихах. По содержанию они могли относиться ко многим областям знания: от истории и географии до политики и права. Арабские лоции, над которыми работал Шумовский, частью изложены в стихах, а заголовки традиционно выписаны ритмической прозой, хотя их авторы и не были поэтами.

Работая над арабскими рукописями, ученый пришел к мысли о необходимости передачи их формы художественными средствами, чтобы не лишать владеющего русским языком читателя возможности испытать те же чувства, которые возникают у образованного араба при чтении оригинала. В своих книгах Шумовский выразил собственные принципы художественного перевода, не приемля рабского следования грамматической структуре оригинала, в чем не был одинок. Поиски более адекватных средств художественного перевода волновали крупнейших представителей русского востоковедения XX в., таких как китаист В. М. Алексеев или специалист по литературе древнего Ближнего Востока И. М. Дьяконов [18, с. 13-18; 19, c. 6-12].

Классическая арабо-мусульманская научная и литературная традиция предполагала цитирование и комментирование трудов предшественников. Многое в сочинениях об арабской морской географии невозможно понять без обращения к истории средневековой навигации и более широкому пласту культуры того времени. Свой комментарий к прочтению средневековых арабских лоций XII-XVI вв. дает и автор «Арабов и моря». Во вторую главу вошли увлекательные экскурсы о морских путешествиях и открытиях на Ближнем Востоке и в Африке со времен Древнего Египта и Финикии до правления арабских халифов и османских султанов.

Кроме адмиралов, политиков и торговцев, на ее страницах мы встречаемся с учеными и поэтами. Не раз автор цитирует и Коран, причем в собственном поэтическом переводе, работать над которым он начал в середине $\mathrm{XX}$ столетия, когда первое издание книги только готовилось к печати, а закончил через тридцать лет - в 1995 г. [20].

Внимательному читателю несложно заметить особенность переводов Шумовского: они становятся сухими и дословными, когда речь идет о лоциях и морском деле, и намного более раскованными и свободными в художественных арабских текстах, включая айаты Корана. Более последовательно автор претворяет свои соображения о значении художественного перевода во всем, что касается менее специальных, чем мореплавание, областей средневековой арабо-мусульманской культуры. 
В ученом мире Ленинграда к Шумовскому относились с опаской. Он шокировал коллег-востоковедов парадоксальными идеями, несколько эгоцентричным стилем своих научно-популярных работ, борьбой с научным каноном, порой резкими суждениями о мэтрах отечественного востоковедения, не исключая его собственных учителей, и склонностью к мистификации. В книге «У моря арабистики» он опубликовал в стихотворном переводе отрывки из своей уникальной находки - сборника (диван) арабских стихов под пряным восточным заголовком «Лепестки золотой розы», созданным неизвестным мировой арабистике «Атааллахом, прозываемым Ширвани, а родом из Аррана, ученым и поэтом из Ширвана» XV в. По его словам, он случайно нашел эту средневековую рукопись в святилище (nup) при шиитской мечети в Шемахе «в знойный июльский полдень $<$...> памятного 1936 года», когда приезжал к родным на летние каникулы [1, с. 175-182; 2, с. 54-64]. С трудом он разобрал текст древней рукописи, перевел в 1936-1938 гг. большую часть ее стихов на русский язык, даже датировал ее завершение по цитате одного из стихотворений 840 годом хиджры (от 16 июля 1436 по 4 июля 1437 г.), посвящая изучению источника каждую минуту, свободную от занятий над арабскими лоциями. По словам переводчика, оставленные в студенческом общежитии рукопись и русский перевод бесследно пропали к 1949 г. [2, с. 190-192], после первого ареста, но, благодаря своей великолепной памяти, Шумовский сумел восстановить переводы.

Вся эта история вызывает много вопросов и недоумений. Почему Шумовский не поделился своей находкой за полтора года, в течение которых переводил «Лепестки золотой розы», с И. Ю. Крачковским и другими ленинградскими арабистами. Они бы помогли ему точнее идентифицировать уникум. Почему, ощущая приближение ареста, он не решил доверить рукопись одной из востоковедных библиотек города? Почему, вернувшись к научному творчеству, он впервые заявил об уникальной находке не в авторитетном академическом журнале, который с радостью бы принял такую статью, а в популярной книге мемуаров, выпущенной почти через 40 лет после обнаружения стихов Аррани.

Странно, что имя азербайджанского поэта поразительно совпадает с именем переводчика - на арабском 'Ата Аллах означает "дар Божий», равно как и греческое Теодор, - месяц находки соответствует месяцу завершения Дивана. Необычно и то, что в стихах отражены социальные темы протеста против тирании, призывы к веротерпимости, по словам «переводчика» опередившие эпоху Аррани и явно более созвучные ученому и поэту жестокого к людям и индивидуалистского XX столетия, чем века XV.

Однако в ученых кругах Ленинграда мистификация ученого, выдавшего собственные стихи за произведение средневекового земляка из Ширвана, не была тайной. В 1977 г. в печати ее разоблачила ученица И. Ю. Крачковского А. А. Долинина [17, с. 418-422]. Она отметила у Шумовского 
лингвистические и хронологические неувязки (знакомство Аррани с творчеством Руставели), отсутствие адекватного арабского текста подлинника, невозможные для средневековых арабских стихов стиль и манеру изложения мыслей современника XX в. А. А. Долинина нашла в «переводах» из мифического Аррани банальные цитаты из Гёте («Остановись мгновенье, ты прекрасно!»), перепевы Пушкина («Дар мгновенный, дар печальный, Жћизнь на смерть осуждена!» и др.), Уитмена в декадентских переводах Бальмонта («Хочу раскаленных слов, Железо сверлящих слов! На бледных и вялых стремительно-алых, Хочу небывалых слов!»), Гумилева («От старинного мостика, разбегаясь, сутулится, По холмам за мечетями, зарываясь в песок, Затравевшая, бывшая знаменитая улица, Где прошли с караванами и Закат, и Восток»), Ахматовой («И уснула влюбленной, не зная, что в мире живущих Умирает любовь, потому что Стареют сердца») и даже эстрадных песенок и жестоких романсов начала ХХ в. («Над нами безумствует вьюга, Разомкнуты наши пути. Но сердцу и памяти друга От вас никуда не уйти» и проч.). По мнению А. А. Долининой, Шумовский не имел права так мистифрицировать простодушных читателей своей научно-популярной книги.

Не будем слишком сурово судить ленинградского ученого и поэта из Ширвана, пытавшегося нащупать в море арабистики свой путь к сердцам средневековых героев и современных читателей. Популярные очерки Шумовского являются не научным произведением, но автобиографической исповедью историка-ориенталиста в стихах и прозе. В то время для него это был единственный способ опубликовать свои нонконформистские идеи и мысли о противостоянии ученого и Левиафана советского государства. Он пытался высказать некоторые итоги своих поисков художественного перевода с литературного арабского языка на русский.

Не со всем в его подходе к переводческой деятельности и стилю изложения я могу согласиться, но поставленная ширванским арабистом задача крайне важна. Реализовать свои идеи художественного перевода Шумовскому удалось в основном после ухода из Института востоковедения и падения советского строя.

В 80-е годы XX в. он приступил к переводу Корана. Работа отняла у него много времени и была завершена только к 1995 г., когда, наконец, в Москве появился выполненный Шумовским первый русский стихотворный перевод памятника. Такой труд является, пожалуй, венцом стремлений всякого крупного востоковеда. Достаточно вспомнить, скажем, прославленного фрранцузского магрибиста Ж⿱㇒⿻上а Берка, который посвятил переводу Корана на фрранцузский язык последние годы своей жизни, отойдя от занятий социологией мусульман Магриба и арабского Ближнего Востока [21]. Сходные примеры были и в судьбах других ориенталистов XIX-XX вв.

Насколько нужен такой перевод? Коран не раз переводился с арабского на русский. Кроме изданного посмертно чернового перевода И. Ю. Крачковского есть дореволюционные переводы Г. С. Саблукова и Д. Н. Богуслав- 
Бобровников В. О.

ского. Почему же попытки перевести Коран не прекращаются? Дело в том, что все названные переводы передают лишь содержание памятника, пренебрегая его художественными особенностями. Перевод И. Ю. Крачковского порой тяготеет к практически недоступному для понимания непосвященного читателя комментарию. Между тем арабский Коран представляет собой не только боговдохновенное, но и яркое художественное произведение. Он написан ритмической прозой (садж), близкой по фрорме к поэзии. Надо быть Пушкиным, чтобы по дурному французскому переводу Дю Рие или по его не более удачному русскому переложению М. И. Веревкина понять в XIX в. художественные достоинства Корана, выразив их в его знаменитых «Подражаниях Корану». Русскому читателю все еще не хватает хорошего художественного перевода памятника, продолжающего волновать сердца людей.

Появившийся одновременно с изданием Шумовского новый академический перевод дагестанского востоковеда Н. О. Османова не передает художественную форму «Откровения». Что уж говорить про сделанный в 1993 г. не знающей арабского языка Викторией Пороховой бессмысленный «перевод смыслов», по существу сводящийся к испорченному «переводу» из И. Ю. Крачковского на бойкий, но малограмотный и не соответствующий оригиналу русский! В этих условиях попытка стихотворного перевода Шумовского была смелым новшеством.

Насколько предложенные Шумовским поэтические формы отражают подлинный художественный строй Корана? Мне лично он кажется слишком далеким от арабского оригинала по стилю и ритмике, напоминая скорее ориенталистские франтазии второстепенных поэтов Серебряного века, находившихся под влиянием переложений средневековых персидских лириков. Однако работы Шумовского отличает повышенное внимание к художественному слову и форме в арабо-мусульманской культуре, что выгодно отличает их автора от «сухого» стиля современных ему арабистов, нередко глухих к эстетическим достоинствам источников.

\section{Ссылки}

1. Шумовский Т. А. У моря арабистики. По страницам памяти и нелзданных документов. М.: Главная редакция восточной литературы издательства «Наука», 1975. 344 c.

2. Шумовский Т. А. Свет с Востока. СПб.: Изд-во Санкт-Петурб. ун-та, 2006. 352 c.

3. Люди и судьбы. Биобиблиографический словарь востоковедов - жертв политического террора в советский период (1917-1991)/Изд. подгот. Я.В. Васильков, М. Ю. Сорокина. СПб.: Петербургское Востоковедение, 2003. 496 с.

4. Шумовский Т. А. Голос памяти (воспоминания сокамерника) // Восток. 2004. № 4. C. 141-142.

5. Шумовский Т. А. Воспоминания арабиста. Л.: Наука, 1964. 172 с. 
6. Книга тысячи и одной ночи: в 8 т. / пер. с араб. М. А. Салье, предисл. М. Горького и М. А. Салье; под ред. акад. И. Ю. Крачковского. М.; Л.: Academia, Гослитиздат, 1932-1939.

7. Ал-Махри, Сулайман. Махрийская опора для точного определения [основ] морских наук / ал- 'Умда ал-махриййа фри дабт ал-'улум ал-бахриййа / пер., ком., сравнит. анализ списков Т. А. Шумовского; под ред. А. С. Матвеева. М.: Марджани, 2011. 426 c.

8. Шумовский Т. Арабы и море. По страницам рукописей и книг. М.: Наука, 1964. 193 с.; 2-е изд. / под ред. В. О. Бобровникова. М.: Марджани, 2010. 192 с.

9. Ле Гоффр Ж. Цивилизация средневекового Запада. Екатеринбург: Е-Фактория, 2005. 560 с.

10. Милибанд С. Д. Биобиблиографический словарь советских востоковедов. M., 1975. 733 c.

11. Шумовский Т. А. Три неизвестные лоции Ахмада ибн Маджида, арабского лоцмана Васко Да-Гамы в уникальной рукописи Института востоковедения АН СССР / предисл. Д. А. Ольдерогге; отв. ред. И. А. Орбелли. М.; Л.: Изд-во AH CCCP, 1957. 195+ 46 c.

12. Lokhova S. The Spy who Changed the World. The Untold Story of How the Soviet Union Won the Race for America's Top Secrets. New York: Harper Collins, 2019. $476 \mathrm{p}$.

13. Três roteiros desconhecidos de Aḥmad Ibn-Mādjid, o piloto árabe de Vasco da Gama / [Por] T. A. Chumovsky. Tradução portuguesa do prof.dr. Myron MalkielJirmounsky. Lisboa: Comissão Executiva das Comemorações do v Centenário da morte do Infante D. Henrique, 1960. 195 p.

14. Салас азхар фри ма'рифрат ал-бихар Ахмад б. Маджид маллах Фаску ди Гама / Тахкик Теодор Шумовский тарджамат ва-та'лик Мухаммад Мунир Мурси. Каир: 'Алам ал-кутуб, 1969. 237 с. (на араб. яз.).

15. Revue de l'Institut des manuscrits arabes. Vol. 4. Fasc. 2. Le Caire, 1958. P. 349.

16. Бартольд В. В. Коран и море // Бартольд В. В. Работы по истории ислама и Арабского халифата. М.: Восточная литература, 2002. С. 544-548.

17. Долинина А. А. Арабески: избранные научные труды. СПб.: Нестор-История, 2010. 444 c.

18. Антология китайской лирики VII-IX вв. по Р. X. / пер. в стихах Ю. К. Щуцкого; ред., ввод. обобщения и предисл. В. М. Алексеева. М.-Пб.: Гос. издво, 1923; сер. «Всемирная литература». 144 с.

19. Дьяконов М. М., Дьяконов И. М. Избранные переводы. М.: Главная редакция восточной литературы изд-ва «Наука», 1985. 256 с.

20. Коран: Священная книга мусульман / пер.с араб. и предисл. Т. А. Шумовского. M.: Терра, 1995. 528 с.; 2-е изд. 2001; 3-е изд. 2004.

21. Le Coran / Trad. par J. Berque. P.: Albin Michel, 1995. 844 p. 